\title{
Review of the Views of Secondary School Maths Students on Skills- Based Questions
}

\section{OPEN ACCESS}

Volume: 9

Special Issue: 2

Month: September

Year: 2021

E-ISSN: 2582-1334

Received: 15.07.2021

Accepted: 22.08.2021

Published: 15.09.2021

Citation:

Nayıroğlu, Büşra, et al. "Review of the Views of Secondary School Maths Students on Skills- Based Questions." Shanlax International Journal of Education, vol. 9, no. S2, 2021, pp. 105-11.

DOI:

https://doi.org/10.34293/ education.v9iS2-Sep.4375

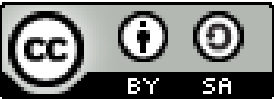

This work is licensed under a Creative Commons Attribution-ShareAlike 4.0 International License

\author{
Büşra Nayıroğlu \\ Ministry of National Education, busra, Syria, Turkey \\ https://orcid.org/0000-0003-2440-2445
}

\section{Tayfun Tutak}

Firat University, Turkey

https://orcid.org/0000-0002-0277-6377

\author{
Ahmet Melih Tutak \\ Ministry of National Education, Turkey \\ https://orcid.org/0000-0002-7200-8832
}

\begin{abstract}
In this study, secondary school mathematics teachers' the opinions related to skills-based questions that are compatible with the LGS (High School Transition Exam) question style were examined. Qualitative research methods were adopted in the study. Mathematics teachers working in secondary schools in various parts of Turkey participated in the study.The data is collected via the semi-structured interview form via the "Google drive". Content analysis was used in data analysis. The findings revealed that maths teachers did not agree with the achievements of their skill-based questions, and that the maths course's teaching programs and textbooks were not sufficient to provide effective guidance on skills-based questions. It turns out that teachers need a new course processing process for skill-based questions such as LGS questions. Therefre, it was discovered that they were experiencing a shortage of resources. It was also identified that teachers needed to read books and need in-service training as skill-based questions are questions to understand and interpret what they are reading. Recommendations were made in accordance with the results. Keywords: Skill-based questions, PISA, Mathematics teachers.
\end{abstract}

\section{Introduction}

The importance of education is constantly increasing due to the continuous changes in the world. Societies grasping this importance have made education compulsory for individuals. Educated individuals have a fundamental impact on the development of their society. The Ministry of National Education (MEB) in Turkey has made a series of changes in the curriculum, central exams and transition system between levels in recent years. In the background of these changes in education, it can be said that there may be social, cultural and economic reasons, as well as the results of international exams such as PISA and TIMSS (MEB 2005; Board of Education 2017). Similarly, it can be stated that it is applied for the education systems of other countries (Breakspear 71; Harus and Davidovitch 9-21; Jürges, Schneider and Büchel 1134-1155; Woessmann).

In 2018, TEOG (Basic Education to Secondary Education Transition Exam), which was applied to secondary education, was removed and LGS was introduced for the first time. This exam intends to help students interpret, conclude, solve problems, analyze, think critically, and measure scientific process skills (MEB, 2018c). 
The examination of the questions withregard to form shows that LGS and PISA questions are similar in terms of attributes such as problem solving, analyzing, and reasoning. In addition, one of the innovations that LGS has brought has been skillbased questions. It may be said that this type of question has been passed on to Turkey mostly through the PISA and TIMSS exams. The questions measure thestudent's effective participation in society, the development of knowledge and potential, and the ability to contribute to the environment in which it is present (Suna, Tanberkan, Taş, Eroğlu and Altun). In this context, it adopts a skill-based test model, which is referred to as 'native PISA and TIMSS' (Sezer). The experience obtained here is intended to be used in secondary education and university exams. The ministry aims to eliminate uncertainties and increase students' experience in skill-based questions with sample questions shared each month before the exam (MEB, 2018a). When skill-based questions are compared with previous exam questions, it can be said that there are differences that need to be dwelled on (Güler and Ülger 337-363). In TEOG exams, questions are mostly at the level of knowledge and comprehension (Özden, Akgün, Çinici, Sezer, Yıldız, Taş 91-108), while higher-level questions are asked in LGS exams (Batur, Ulutaş Berut 595-615; Ekinci Bal 9-18; Kilkapan Nacaroğlu 701-719). In this context, MEB aims to measure students' high-level skills such as reading comprehension, interpretation, inference, problem solving, analyzing, critical thinking, and scientific process skills through skillbased questions (MEB, 2018c). In addition, it can be stated that the questions are prepared on a solid ground by establishing a relationship with daily life. It can be said that the LGS exam (Madaus 29-46), which has a higher risk level for students than other types of exams, and the skill-based questions asked in this exam are extremely important in determining the academic success of students. Examining teachers' views on skill-based questions is very important for at least three reasons. The first is that teachers' opinions are taken into account in the creation of skill-based questions that require higher level thinking skills and focus on daily life compared to the knowledge / recall-based exam questions that have been criticized for years and are said to be 'based on memorization'. In addition, it can provide important contributions for these questions to be more consistent with the achievements and content of the current curriculum and to determine the scope of the questions in a much more realistic way. Second, in order to use these questions in line with the acquisition and content of the current curriculum, a situation determination regarding the quality of the textbooks used in schools is also needed (ERG). In determining this need, as is the case for almost every level of education, teachers' views constitute one of the important data sources (Eisner; Levine 52-60). Thirdly, and more importantly, considering that teachers constitute the group with the most comprehensive information about the current knowledge levels, skills and similar issues of students who are the subjects of the teaching process (Hallinan 271-283; Schmoker), the findings of this study can be beneficial for the student to be created according to the principle of relativity and based on a more solid ground. In this context, it becomes even more important to determine the opinions of middle school mathematics teachers about the skill-based questions about the mathematics lesson published by the Ministry of Education. Hence, the aim of this study was to examine the examination of teachers' opinions on the skill-based questions asked for the mathematics lesson. Three research questions were created in line with the purpose of the study.

The teachers;

1. What are the views of the skill-based questions on the compatibility with the achievements for the mathematics lesson?

2. What are the opinions of the mathematics curriculum about the guidance of the skill-based questions?

3. What are the opinions about the effects of skill-based questions on learning and teaching processes?

\section{Purpose of the Research}

The aim of this study is to determine the skillsbased questions of the mathematics teachers working in secondary school related to the maths class published by MEB. 


\section{Research Method}

In this study, it was aimed to investigate the opinions of secondary school mathematics teachers about the skill-based questions in mathematics textbook by the Ministry of Education. For this reason, the research was conducted with the phenomenology design, one of the qualitative research methods. Phenomenology is a method that focuses on evaluating personal experience (Jasper 309-314; Miller 6882 ). Phenomenology primarily tries to describe the world experienced by individuals and explain the essence of lived experiences in order to discover the common meanings underlying the phenomenon (Baker, Wuestand Stern 1355-160; Rose, Beeby and Parker1123-1129). Therefore, in phenomenology, it is emphasized that there is a connection between the people who have experienced the phenomenon and the phenomen on, and the starting point of phenomenology is the facts themselves. This research method borrows experiences from individuals to describe and interpret the experiences of individuals (Jasper 309-314; Miller 68-82). Thus, all phenomena experienced by individuals can be investigated and explained (Baker et al.1355-160).

Study group 70 mathematics teachers working in secondary schools in various parts of Turkey was participated in this study. The participation was on voluntary basis.

\section{Data Collection Tools}

As a data collection tool, the semi-structured interview form developed by the was used. The interview form was prepared by the researchers. The prepared interview form was applied to 50 teachers and they provided feedbacks, except for the example of the first step work. As a result of the feedbacks, the required corrections were made on the interview form and shown to six educators who are experts in the field. As a result of the feedbacks form the field qualified educators, the interview form was finalized. In addition, the required corrections were made in terms of language and comprehension by a Turkish language teacher.

\section{Data Collection and Analysis}

The data was collected via the semi-structured interview form via the "Google drive". Content analysis was used in the analysis of the data. The process of content analysis is to combine similar data within the framework of specific concepts and themes and interpret them in a way that the reader can understand (Yıldırım and Şimşek).

\section{Findings}

In this part of the study, findings from the analysis of the data collected is presented to answer the skills-based questions of the maths teachers working in secondary school related to the maths lesson published by MEB.

Table 1: Teachers' Insights on Skills-based Questions in Compliance with Course gains

\begin{tabular}{|c|l|c|c|}
\hline \multicolumn{1}{|c|}{ Category } & Vision & Frequency & Percent \\
\hline Maths Skills- & Yes & 13 & 18.5 \\
\cline { 2 - 4 } Based Questions & Partially & 21 & 30 \\
\cline { 2 - 4 } & No & 36 & 51.5 \\
\hline & Total & 70 & 100 \\
\hline
\end{tabular}

As shown in Table 1, 18.5\% of the maths teachers stated that the skill base questions were compatible with course gains, $30 \%$ were partially compatible, and $51.5 \%$ were incompatible.

Table 2: Analysis Results on the Conformance of Skill-based Questions with Course gains

\begin{tabular}{|c|l|l|c|}
\hline Category & & \multicolumn{1}{|c|}{ Codes } & f \\
\hline \multirow{4}{*}{ Maths Skills- Bas Questions } & \multirow{4}{*}{ Incompatible } & Covering top-level skills in geese & 16 \\
\cline { 3 - 4 } & & Overlap with gains and explanations & 13 \\
\cline { 3 - 4 } & & Give a different look at the gains & 11 \\
\cline { 3 - 4 } & \multirow{4}{*}{ Compatible } & Change of winnings & 35 \\
\cline { 3 - 4 } & & Overrated questions & 15 \\
\cline { 3 - 4 } & & Long questions & 17 \\
\cline { 3 - 4 } & & Ability to measure different skills & 14 \\
\hline
\end{tabular}


In Table 2, it is seen that 16 participants thought that skill-based questions included higher level acquisitions, 13 stated that they overlapped with gains and explanations, and 11 provided a different perspective to the outcomes. Accordingly, it can be stated that mathematics teachers considered the lesson outcomes compatible with the skill-based questions. From the math teachers; He did not find the skill-based questions compatible with the course outcomes due to the reasons that questions are much higher than the level ofacquisitions $(\mathrm{f}=35)$, exaggerated questions ( $\mathrm{f}=15)$, long questions $(\mathrm{f}=17)$, and of a quality measuring different skills $(\mathrm{f}=14)$.

Table 3: Results on the Guidance of the Teaching Program in Solving Skills-based Questions

\begin{tabular}{|c|l|c|}
\hline Category & \multicolumn{1}{|c|}{ Codes } & $f$ \\
\hline \multirow{2}{*}{$\begin{array}{c}\text { Maths Skills- } \\
\text { Based Questions }\end{array}$} & $\begin{array}{l}\text { There are no exemplary } \\
\text { events for the gains. }\end{array}$ & 40 \\
\cline { 2 - 3 } & $\begin{array}{l}\text { There are no examples } \\
\text { of quantification in the } \\
\text { program that apply to } \\
\text { these questions. }\end{array}$ & 36 \\
\cline { 2 - 3 } & There are only gains. & 17 \\
\hline
\end{tabular}

As shown in Table 3, teachers stated that programs could not guide the solution of skillsbased questions due to lack of learning-teaching process and measurement evaluation.

Table 4: Teachers' Insights on the Guide to the Skill-based Questions of Course Books

\begin{tabular}{|c|c|c|c|}
\hline Category & Vision & Frequency & Percent \\
\hline \multirow{2}{*}{$\begin{array}{c}\text { Maths } \\
\text { Skills- } \\
\text { Based }\end{array}$} & Yes & 4 & 5.7 \\
\cline { 2 - 4 } Questions & Partially & 6 & 8.5 \\
\cline { 2 - 4 } & No & 60 & 85.7 \\
\cline { 2 - 4 } & Total & 70 & 100 \\
\hline
\end{tabular}

As shown in Table 4, 5,7\% of the participants stated that the teaching program provided guidance on the solution of skill-based questions, $8,5 \%$ stated that it partially did, and $85,7 \%$ expressed that it did not guide.
Table 5: Results on the Impact of Skill-based Questions on Learning-Teaching Processes

\begin{tabular}{|c|l|c|}
\hline Category & \multicolumn{1}{|c|}{ Codes } & $\boldsymbol{f}$ \\
\hline \multirow{4}{*}{$\begin{array}{c}\text { Maths Skills- } \\
\text { Based Questions }\end{array}$} & Resource shortage & 67 \\
\cline { 2 - 3 } & The new lecture process & 33 \\
\cline { 2 - 3 } & Undifferent students & 30 \\
\cline { 2 - 3 } & Reading habit & 12 \\
\hline
\end{tabular}

When table 5 was examined, maths teachers focused their views on five different variables about the impact of skill-based questions on the learningteaching process. These were resource shortages $(\mathrm{f}=67)$, new course processing process $(\mathrm{f}=33)$, unrelated students $(\mathrm{f}=30)$, reading habits $(\mathrm{f}=12)$.

In light of the findings outlined above, it may be said that maths teachers have similar views on the impact of skill-based questions on learningteaching processes. In detail, teachers stated that they needed a new course processing process with PISA-style questions, they needed to read books and they needed in-service training as they had questions about understanding that they were experiencing resource shortages.

\section{Conclusions and Recommendations}

This study was conducted to determine the opinions of the mathematics teachers working in secondary school regarding the skills-based questions published by MEB regarding the maths class. The findings in this study showed that teachers tend to think that skill-based questions are not compatible with the achievements of teaching programs in mathematics and that the teaching programs and textbooks of mathematics are not sufficient to provide effective guidance on skills-based questions. The findings also revealed that teachers tend to explain the impact of skill-based questions on education environments, regardless of their area of expertise, through new teaching processes, lack of resources, reading habits and vocational education concepts to teachers.

A significant number of mathematics teachers thought that the skill-based questions and lesson outcomes were not fully compatible, the questions had over-acquisition, exaggerated and long content, and they measured different qualities of skills. In this context, when 2018and 2019 LGS evaluation 
reports are examined, findings supporting the views of mathematics teachers are encountered (MEB, 2018b, 2019b). Considering the research findings, it can be stated that the achievements in the program and the skill-based questions are not compatible with each other. Therefore, it can be said that there is a real reason why mathematics teachers think that they have an over-acquisition, exaggerated and long content for skill-based questions. As a matter of fact, the reasons why the curriculum could not provide the necessary guidance for the skill-based questions were the high difficulty level of themathematics questions in the program (Güler, Arslan Çelik,337-363), the educational situation and measurement that caused students to experience the feeling of failure and as a result, their distancing from the mathematics course. - They explained by omitting the evaluation element. While enumerating the reasons for failure, the teachers mentioned the dominant characters of the multiple-choice exams in the system in our education system and the test technique. Secondly, the concepts that stand out under the title of content, learning and implementation under the program theme, which is mentioned a lot, are the program, the teaching process and the application process. The third issue that the teachers mentioned under the student theme, which they frequently touch upon, is related to the quality of the education they received until the eighth grade. Lack of pre-learning, lack of motivation, lack of association with life, analytical thinking, etc. are issues that a qualified learning environment can gain and eliminate over time. Especially the difficulty level of math questions is high (Güler, Arslan Çelik, 337-363) It may have caused students to experience a sense of failure and, as a result, to stay away from mathematics class. In order for such questions to be better understood and answered correctly, students should gain the habit of reading books from an early age.

It was determined that in the item "What to do in order to gain students the basic competencies required to answer the math questions correctly, to gain the habit of reading a book, to solve questions about daily life problems, to eliminate basic mathematical deficiencies, and to prefer modern teaching methods" were found to come to the fore. In the study conducted by Yaprakgül, it was determined that
PISA questions require intuitive thinking, learning through discovery, and were prepared about daily life problems by taking into account social problems and needs. In a different study, it was concluded that using modeling activities in lessons and associating mathematics with daily life will increase the success in exams (Şahin and Eraslan, 373-393).

Considering the MEB exam analysis and other research findings that support these opinions of teachers, the following suggestions can be made:

- While preparing sample skill-based questions for LGS and mathematics lessons, it may be necessary to consider the principle of student relativity for a valid and reliable assessment and evaluation process. In this context, the difficulty level of mathematics questions, their compatibility with the gains, the length of the questions and the time allocated to the questions can be evaluated holistically.

- Considering that mathematics questions try to measure higher level skills, achieving a basic harmony between the acquisitions and questions can increase the harmony between the learningteaching processes of the curriculum and the measurement- evaluation elements.

- In order to eliminate the problems of skillbased teaching and counseling in question solving, which arise from insufficient inclusion of educational situations and assessment and evaluation elements in the curriculum, the characteristics of skill- based questions can be taken into account and accordingly, these items can be developed in a more comprehensive and balanced manner.

- Taking teachers' opinions into account in the process of creating LGS-like exam questions may increase the validity and reliability of the exam questions.

- Comparative experimental studies to be conducted to understand how skill-based questions affect the teaching process in mathematics lessons in the future may reveal more reliable findings on this issue.

- This study is limited to the opinions of middle school mathematics teachers. Therefore, similar studies can be done in other branches. 
References

Baker, Cynthia, et al. "Method Slurring: The Grounded Theory / Phenomenology Example." Journal of Advanced Nursing, vol. 17, 1992.

Batur, Zekerya, et al. "Investigation of 2018 LGS Turkish Questions for PISA Reading Skills Objectives." Milli Egitim, no. 48, 2018, pp. 595-615.

Breakspear, Simon. "The Policy Impact of PISA: An Exploration of the Normative Effects of International Benchmarking in School System Performance." OECD Education Working Paper 71, 2012.

Central Examination, Education Analysis and Evaluation Reports Series Regarding Secondary Education Institutions. Turkish Ministry of National Education, 2019b.

Eisner, Elliott W. The Educational Imagination: On the Design and Evaluation of School Programs. Macmillan, 1994.

Ekinci, Onur, and Ayten Pinar Bal. "Evaluation of High School Entrance Exam (LGS) 2018 in Terms of Mathematics Learning Field and Revised Bloom Taxonomy." Journal of Social Sciences of Mus Alparslan University, vol. 7, no. 3, 2019, pp. 9-18.

Eğitim İzleme Raporu 2019. ERG, 2019, www. egitimreformugirisimi.org/wp-content/ uploads/2010/01/EIR_Egitimin_Icerigi.pdf

Güler, Mustafa, et al. "Mathematics Teachers' Views on the 2018 Entrance Exam for High Schools." YYU Journal of Education Faculty, vol. 16, no. 1, 2019, pp. 337-363.

Gün, Mesut, and İlhami Kaya. "Evaluation of Turkish Teachers 'Relationships Between the Revolved Secondary School Transition System." The Journal of Academic Social Science Studies, no. 71, 2018, pp. 67-79.

Hallinan, Maureen T. "Teacher Influences on Students' Attachment to School." Sociology of Education, vol. 81, no. 3, 2008, pp. 271283.

Harus, Eli Ben, and Nitza Davidovitch. "The GEMS Exams in Israel - Between Center and Periphery." International Education Studies, vol. 12 , no. 10, 2019, pp. 9-21.
High School Transfer System Student Performance Placed through Central Exam, Education Analysis and Evaluation Reports Series. Turkish Ministry of National Education, $2018 b$.

Jasper, Melanie A. "Issues in Phenomenology for Researchers of Nursing." Journal of Advanced Nursing, 19.2 (1994): 309-314.

Jürges, Hendrik, et al. "The Effect of Central Exit Examinations on Student Achievement: Quasi-experimental Evidence from TIMSS Germany." Journal of the European Economic Association, vol. 3, no. 5, 2005.

Kızkapan, Oktay, and Oğuzhan Nacaroğlu. "Science Teachers' Opinions on Central Exams (LGS)." Nevşehir Hacı Bektaş Veli Üniversitesi SBE Dergisi, vol. 9, no. 2, 2019, pp. 701-719.

Levine, David. "Building a Vision of Curriculum Reform." Rethinking Schools: An Agenda for Change, edited by David P Levine, et al., W.W. Norton, 1995.

Madaus, George F. "The Distortion of Teaching and Testing: High-Stakes Testing and Instruction." Peabody Journal of Education, vol. 65, no. 3, 1988, pp. 29-46.

Primary Education 1-5 Class Schedules Introduction Handbook. Turkish Ministry of National Education, 2015.

Ministry of National Education Directive for Transition to Secondary Education. Turkish Ministry of National Education, 2018.

2023 Education Vision. Turkish Ministry of National Education, 2018a.

Miller, Sue. "Analysis of Phenomenological Data Generated with Children as Research Participants." Nurse Researcher, vol. 10, no. 4, 2003, pp. 68-82.

Müfredatını Yenileme ve Değiştirme Çabalarımı Üzerine. Eğitim Kurulu. 2017.

Özden, Mustafa, et al. "Analysis of Science Questions used in Central System Common Exam According to Webb's Dok Levels." Adiyaman Üniversitesi Fen Bilimleri Dergisi, vol. 4, no. 2, 2014, pp. 91-108.

Rose, Pat, et al. "Academic Rigour in the Lived Experience of Researchers using Phenomenological Methods in Nursing." 
Journal of Advanced Nursing, vol. 21, no. 6, 1995.

Schmoker, Mike. Focus: Elevating the Essentials to Radically Improve Student Learning. ASCD, 2018.

Sezer, Sefa. Akademik Becerilerin İlenmesi ve Değerlendirilmesi. Milli Eğitim Bakanlığı ABIDE, 2019.

Suna, Hayri Eren, et al. Turkey PISA 2018 Preliminary Report. Ministry of Education, 2019.

Şahin, Neslihan, and Ali Eraslan. "MiddleSchool Prospective Mathematics Teachers' Opinions on the Use of Modeling Activities at the Course of Mathematics Applications."
Turkish Journal of Computer \& Mathematics Education, vol. 10, no. 2, 2019, pp. 373-393.

Woessmann, Ludger. "Central Exit Exams Improve Student Outcomes." IZA World of Labor, 2018

Yaprakgül, Sevgi. Ortaöğretime Geçis Sinavlari (TEOG, LGS) Ile PISA, TIMSS Sinavlari Matematik Sorularinin Matematiksel ve Matematik Ĕgitimi Değerleri Açisindan Incelenmesi. Erzincan Binali Yıldırım University, 2019.

Yıldırım, Ali, and Hasan Şimsek. Sosyal Bilimlerde Nitel Araştırma Yöntemleri. Seçkin Publishing, 2011.

\section{Author Details}

Büşra Nayıroğlu, Ministry of National Education, busra, Syria, Turkey, Email ID: brnrl@gmail.com

Tayfun Tutak, Firat University, Turkey, Email ID: tayfuntutak@hotmail.com

Ahmet Melih Tutak, Ministry of National Education, Turkey,Email ID: melihtutak@hotmail.com 